\title{
Analysis of Students' Aptitude and Academic Performance: Input to Curriculum Enhancement
}

\author{
Shalom Grace C. Sugano \\ Faculty, College of Education, Visayas State University, Visca, Baybay City, Leyte. Philippines, \\ shalomgrace.sugano@vsu.edu.ph
}

Leo A. Mamolo

Faculty, College of Education, Visayas State University, Visca, Baybay City, Leyte. Philippines, leomamolo@gmail.com,leo.mamolo@vsu.edu.ph

\begin{abstract}
The need to assess and understand students' strengths in choosing their future careers is essential. Aptitude exams like the National Career Assessment Examination (NCAE) and Academic performance via Grades are important data used as the basis for determining student career strength. This study employed descriptive-correlational research, where secondary data were used. The analysis of NCAE results and the academic performance of Grade 10 students were performed in this study. An Independent Sample T-test was also used to determine the significant difference in the two aptitudes/tracks; Technical-Vocational (T.V.) and Academic Track (AT). The study revealed that the majority of the students performed above average and average levels across all domains. Natural Science, Spiritual Vocation, and Science were the students' most preferred careers/occupations. The results also showed a weak positive association between Mathematical Ability and Math performance. However, an insignificant relationship was observed on the two sets of variables; the Science Grade and Scientific Ability scores, and the English Grade and Reading Comprehension and Verbal Ability scores. The study revealed that students have higher AT scores than T.V.; thus, identified as the students' career strength. Evaluation and monitoring program with provisions to motivate students to perform better in the National Standardized Exams is recommended in the study.
\end{abstract}

Keywords: academic performance, aptitude test, career assessment, career track/strand, curriculum

\section{INTRODUCTION}

Education is a vehicle of knowledge, self-preservation, and success (Bhardwaj, 2016). The primary aim of education is to help each individual in society attain their potential and enhance their capabilities. It paves the way for the holistic development of the individual, society, and the nation (Bhardwaj, 2016). Moreover, it helps individuals participate in society's basic functions and acquire an essential educational foundation for their development into a productive and versatile citizen (UNESCO, 2010). Blaschke (2012), as cited in Olaniran (2016), emphasized that developing lifelong learners who can survive and thrive in a global knowledge economy should be the primary concern of every educator. Teachers should educate students and ensure that they are challenged academically and prepared for participation in a global environment (Wagner, 2016).

In response to globalization, the Philippines sets its way in providing $21^{\text {st }}$-century education longing to provide quality education to attain excellence learning, appropriate teaching, and advance resource teachers (Masuhay \& Herrera, 2019). Filipinos give utmost importance to education, for it is crucial to have a stable job to eventually elevate social status. Thus, the education sector emphasizes that the

Citation: Sugano, S. G. C., \& Mamolo, L. A. (2021). Analysis of students' aptitude and academic performance: Input to curriculum enhancement. Anatolian Journal of Education, 6(2), 51-62. https://doi.org/10.29333/aje.2021.625a 
learning process's whole facet shall ensure the provision of quality and relevant education. Curricular programs and educational reforms should help learners adapt to the changing nature and enhance their capability to learn, acquire, and apply new skills throughout their lives (Camacho, 2012).

The Enhanced Basic Education Act of 2013 is the largest education reform in the Philippine educational system (Department of Education, 2014). The new curriculum, $\mathrm{K}$ to 12, is a landmark reform that brings the country's basic education at par with international standards (Ednave et al., 2018). It seeks to provide a quality 12- year basic education program that each Filipino is entitled to. This addresses the Philippine educational system's deficiency, particularly in basic education (Alonzo, 2015). It aims to contribute to an educated society equipped with competencies and skills for life-long learning and employment (Oliveros, 2013). Students will undergo a basic education curriculum consisting of a compulsory one-year Kindergarten and six years of Elementary education. The students proceed with a 4-year Junior high school (Grade 7 to 10) and two years senior high school (Grades 11 to 12). With the K-12 curriculum model, the two years for senior high school aims to give students enough time to strengthen competencies and academic skills (Department of Education, 2010). The curriculum also provides specializations in the following academic areas: Science and technology, music and arts, agriculture and fisheries, sports, business and entrepreneurship, and others depending on the occupation or career the students intend to pursue (Department of Education, 2010).

One of the indicators of students' success is academic performance. It relates to how well a student meets the standard set by the institution. However, good academic performance is not the only measure and determinant of success in the working world. Non-academic factors also matter. As career competitions grow even fiercer, students' importance, especially graduating students, doing well in their studies has centered the attention of parents, legislators, bureaucrats, and educational personnel (UNESCO, 2010). The aptitude, inclination, and skills should be considered, mainly when applying for college and choosing career paths.

According to the Department of Labor and Employment (DOLE), one of the pressing situations that the government wants to address is the job mismatch, to cut the unemployment rate, and reverse the local "brain drain" phenomenon (Tan \& Balasico, 2018). Present conditions indicate that many college graduates fail to find appropriate employment suited for the course they finished (Department of Education, 2011). It has resulted in unemployment and oversupply of college graduates in white-collar jobs while resulting in shortages in skilled human resources. This scenario is strengthened by the fact that learning skills and competencies are usually neglected in basic education. If assessed, it is based on conventional evaluation methods and educational performance measures, which do not realistically account for students' holistic skills and abilities (Tan \& Balasico, 2018).

Assessment is an essential part of the teaching-learning process (Mamolo, 2019). It is a process of collecting information or evidence of a learner's progress and achievement over time to improve teaching and learning (Rao, 2018). Some assessment. Some assessment procedures are designed to compare students' academic performance from different schools, states, nationwide, or worldwide. Conducting assessments can improve the diagnosis of students' and teachers' strengths and weaknesses (Thompson, 2009). In the teaching-learning process, students' aptitude and academic performance can be measured through assessment.

National Career Assessment Exam (NCAE) is one assessment tool for students' aptitude test administered by the Department of Education to address such purpose. It also assesses the career occupational interests of the students. It started in 2016 to help senior high school students pursue the most suitable career (Camacho, 2012). A paper-pencil test utilizes a scannable answer sheet that is processed electronically (Benita, 2015). The examination serves as a career direction scheme by assessing the students' aptitude and potentials to take a four-year college degree program or a vocational-technical course or pursue a career on entrepreneurship (Camacho, 2012). The hope is by

Anatolian Journal of Education, October 2021 • Vol.6, No.2 
determining which careers they are ideally suited for; students can plan a course of study that will give them the skills and education they will need for their ideal careers (Department of Education, 2011). Grade 10 students from all over the secondary schools on both public and private take NCAE as part of the curricular requirement. It envisions providing quality education to students and will be adequately prepared and equipped in the world of work or higher/tertiary education.

This study aims to present substantial information on the analysis of NCAE and academic performance of Grade 10 students. It aims to describe and analyze the students' academic performance, aptitude, and occupational interest/preference in the National Career Assessment Exam. It serves as baseline information in determining the students' career strength that would help curriculum planners evaluate the existing curriculum for senior high school concerning the students' aptitude, interests, and needs. This study mainly aims to describe the aptitude and academic performance of Grade 10 students. Specifically, it aims to answer the following questions:

1. What is the students' aptitude level in each domain of the National Career Assessment Examination?

2. What were the career/occupational interests of VSUIHS Grade 10 students in the NCAE results?

3. Is there a significant difference between student's Technical-Vocational Aptitude and their Academic Track performance?

4. Is there a significant relationship on students',

4.1 NCAE Scientific Ability and Academic Performance in Science,

4.2 NCAE Mathematics Ability and Academic Performance in Mathematics

4.3 NCAE Reading Comprehension and Verbal Ability and Academic Performance in English?

\section{METHOD}

\subsection{Research design}

This study employed a quantitative type of research, specifically descriptive-correlational design. The descriptive-correlational research design allows the researchers to answer questions about the relationship between students' NCAE results and academic performance to determine, describe, and explain certain phenomena (Lappe, 2000). In this study, secondary data was utilized.

\subsection{Document Review}

This study utilized the NCAE Results of the school year 2014-2015, which covers the Occupational Interest Inventory of Students in Secondary Schools (OIISSS) and the final grades of 122 Grade 10 students of Visayas State University Integrated High School (VSUIHS). Science, Mathematics, and English were the three major subjects included in the analysis. VSUIHS is a public high school under the College of Education at Visayas State University located at Visca, Baybay City, Leyte, Philippines.

The overall General Scholastic Aptitude (GSA) score is the average of the standard scores of the Scientific Ability (S.A.), Mathematical Ability (M.A.), Reading Comprehension (R.C.), and Verbal Ability (V.A.). The Technical-Vocational Aptitude (TVA) is the composite of Clerical Ability (C.A.) and Visual Manipulative Skills (VMS) scores. Additionally, the NCAE reports scores in Academic Tracks comprising the following fields: Humanities and Social Science (HUMS), Science, Technology, Engineering and Mathematics (STEM) and Accountancy, Business and Management (ABM). The career/occupational interests of the students were also reflected in NCAE highlighted in OIISSS. Occupational Interest Inventory of Students in Secondary School (OIISSS) is an 
inventory/checklist of the occupational interests that assess inclinations/preferences for comprehensive career guidance.

\subsection{Data Gathering Procedure}

To collect the data, the researchers asked permission for the VSUIHS Principal to get a copy of the students' NCAE results and grades. After securing permission, the analysis followed.

\subsection{Research Data Analysis}

NCAE results reported the students' performance in the assessment exam presented in a graph and tabular standard scores and percentile ranks. In the analysis of data, the percentile rating in GSA, TVA, and AT was used to describe the performance and determine the students' percentage distribution by aptitude level. The aptitude level indicates the level of performance based on the obtained rating on the students. The descriptive rating of the percentile rank is described below;

$\begin{array}{ll}\text { Rating } & \text { Description } \\ 98-99+ & \text { High } \\ 86-97 & \text { Above Average } \\ 51-85 & \text { Average } \\ 3-50 & \text { Below Average } \\ 0-4 & \text { Poor }\end{array}$

Three (3) occupational fields with the highest percentage scores in each student were accounted for and distributed. The mean percentage scores were used to present the top occupational interest. An independent sample T-test was employed to distinguish a significant difference between the students' standard scores in the TVA and AT domains. Also, this is made to determine the track that the students performed better. Pearson Product Correlation was employed to determine the significant association of each of the GSA subtests; S.A., MA, VA, and R.C. to the academic performance in Science, Mathematics, and English, respectively. The standard scores were used in the correlation analysis.

\section{FINDINGS AND DISCUSSION}

The frequency distribution of the students in each of the following NCAE domains is presented in Table 1. Table 1 shows the aptitude level of Grade 10 students in the GSA, TVA, and AT domains. Results show that $50 \%$ ( $\mathrm{n}=61$ students) got above average to high aptitude level in General Scholastic Aptitude, mostly clustered to high category. For the Technical-Vocational Aptitude, 46\% $(n=56)$ performed above average to high, mostly clustered in the above-average level. More than half of the students performed better in the academic track with $21.31 \%(\mathrm{n}=26)$ as high aptitude and $32.79 \%(\mathrm{n}$ $=40)$ as above average. Only $19 \%(\mathrm{n}=23)$ achieved below average to poor aptitude. To note, only one student got poor aptitude in TVA. Hence, the majority of the students performed well on the national career assessment examinations. It indicates that these students have prepared or mastered the competency being measured in the exam. 
Table 1

Frequency distribution of grade 10 students' aptitude level on the different NCAE domains

\begin{tabular}{|c|c|c|c|c|c|c|c|c|c|c|c|c|}
\hline \multirow{3}{*}{ NCAE Domains } & \multicolumn{6}{|c|}{ Aptitude Level } & & & & & & \\
\hline & \multicolumn{2}{|c|}{$\begin{array}{l}\text { High } \\
(98-99+)\end{array}$} & \multicolumn{2}{|c|}{$\begin{array}{l}\text { Above } \\
\text { Average } \\
(86-97)\end{array}$} & \multicolumn{2}{|c|}{$\begin{array}{l}\text { Average } \\
(51-85)\end{array}$} & \multicolumn{2}{|c|}{$\begin{array}{l}\text { Below } \\
\text { Average } \\
(3-50)\end{array}$} & \multicolumn{2}{|c|}{$\begin{array}{l}\text { Poor } \\
(0-4)\end{array}$} & \multicolumn{2}{|c|}{ TOTAL } \\
\hline & $\mathrm{N}$ & $\%$ & $\mathrm{~N}$ & $\%$ & $\mathrm{~N}$ & $\%$ & $\mathrm{n}$ & $\%$ & $\mathrm{~N}$ & $\%$ & $\mathrm{n}$ & $\%$ \\
\hline $\begin{array}{l}\text { General Scholastic } \\
\text { Aptitude }\end{array}$ & 33 & 27.04 & 28 & 22.95 & 40 & 32.49 & 21 & 17.21 & 0 & 0 & 122 & 100 \\
\hline $\begin{array}{l}\text { Technical- } \\
\text { Vocational } \\
\text { Aptitude }\end{array}$ & 7 & 5.74 & 49 & 40.16 & 43 & 35.24 & 22 & 18.03 & 1 & 0.82 & 122 & 100 \\
\hline Academic Track & 26 & 21.31 & 40 & 32.79 & 33 & 27.05 & 23 & 18.85 & 0 & 0 & 122 & 100 \\
\hline
\end{tabular}

Students' performance was then categorized according to the aptitude level in each subtest of the three domains. Table 2 presents the frequency distribution of grade 10 students' aptitude levels on the general scholastic aptitude (GSA) subtest. Base on average to high aptitude level. Results show that many students performed in Reading comprehension and verbal ability with $88.5 \%(\mathrm{n}=108)$ and $81 \%$ $(\mathrm{n}=99)$, respectively. Mathematical ability has $76 \%(\mathrm{n}=93)$ while scientific ability of $73.7 \%(\mathrm{n}=$ 90). The aptitude level in these four subsets is mostly clustered in the average aptitude. Moreover, there are more than 20 students in each subset who garnered high aptitude.

The results imply that the students performed better in the English subject area because the aptitude in Reading Comprehension and Verbal Ability test was higher than the other subsets. Moreover, it is observed that students vary in their aptitude levels in the different subtests indicating that they are heterogeneous learners. Nevertheless, it can be noted that their overall performance is good.

Table 2

Frequency distribution of grade 10 students' aptitude level on general scholastic aptitude subtests

\begin{tabular}{|c|c|c|c|c|c|c|c|c|c|c|c|c|}
\hline \multirow{3}{*}{ GSA Subtests } & \multicolumn{6}{|c|}{ Aptitude Level } & & & & & & \\
\hline & \multicolumn{2}{|c|}{$\begin{array}{l}\text { High } \\
(98-99+)\end{array}$} & \multicolumn{2}{|c|}{$\begin{array}{l}\text { Above } \\
\text { Average } \\
(86-97)\end{array}$} & \multicolumn{2}{|c|}{$\begin{array}{l}\text { Average } \\
(51-85)\end{array}$} & \multicolumn{2}{|c|}{$\begin{array}{l}\text { Below } \\
\text { Average } \\
(3-50)\end{array}$} & \multicolumn{2}{|c|}{$\begin{array}{l}\text { Poor } \\
(0-4)\end{array}$} & \multicolumn{2}{|c|}{ TOTAL } \\
\hline & $\mathrm{N}$ & $\%$ & $\mathrm{~N}$ & $\%$ & $\mathrm{~N}$ & $\%$ & $\mathrm{n}$ & $\%$ & $\mathrm{~N}$ & $\%$ & $\mathrm{n}$ & $\%$ \\
\hline Scientific Ability & 27 & 22.13 & 25 & 20.49 & 38 & 31.45 & 32 & 26.23 & 0 & 0.00 & 122 & 100 \\
\hline $\begin{array}{l}\text { Mathematical } \\
\text { Ability }\end{array}$ & 21 & 17.21 & 26 & 21.31 & 46 & 37.70 & 29 & 23.77 & 0 & 0.00 & 122 & 100 \\
\hline $\begin{array}{l}\text { Reading } \\
\text { Comprehension }\end{array}$ & 26 & 21.31 & 45 & 36.89 & 37 & 30.33 & 13 & 10.66 & 1 & 0.82 & 122 & 100 \\
\hline Verbal Ability & 25 & 20.49 & 27 & 22.13 & 47 & 38.52 & 22 & 18.03 & 1 & 0.82 & 122 & 100 \\
\hline
\end{tabular}

The Technical-Vocational Aptitude Domain is the second and one of the career tracks/strands of senior high school included in the NCAE. Table 3 shows students' frequency distribution by aptitude level in the three subtests of TVA, including Clerical, Non-Verbal, and Visual Manipulative Abilities. Results show that most of the students' aptitude levels in these three subtests are clustered in the average to above-average level with $81.9 \%(\mathrm{n}=100), 81.9 \%(\mathrm{n}=100)$, and $62.3 \%(\mathrm{n}=76)$ respectively. Moreover, none of the group got high aptitude levels in C.A. and NVA, with only eight students in VMA. Although student's aptitude is mostly clustered in the average to above-average levels, results show that students have poor aptitude performance in the TVA domain. These may signify students have few difficulties in the technical vocational domain. 
Table 3

Frequency distribution of grade 10 students' aptitude level on the technical-vocational aptitude subtests

\begin{tabular}{|c|c|c|c|c|c|c|c|c|c|c|c|c|}
\hline \multirow{3}{*}{ TVA Subtests } & \multicolumn{6}{|c|}{ Aptitude Level } & & & & & & \\
\hline & \multicolumn{2}{|c|}{$\begin{array}{l}\text { High } \\
(98-99+)\end{array}$} & \multicolumn{2}{|c|}{$\begin{array}{l}\text { Above } \\
\text { Average } \\
(86-97)\end{array}$} & \multicolumn{2}{|c|}{$\begin{array}{l}\text { Average } \\
(51-85)\end{array}$} & \multicolumn{2}{|c|}{$\begin{array}{l}\text { Below } \\
\text { Average } \\
(3-50)\end{array}$} & \multicolumn{2}{|c|}{$\begin{array}{l}\text { Poor } \\
(0-4)\end{array}$} & \multicolumn{2}{|c|}{ TOTAL } \\
\hline & $\mathrm{N}$ & $\%$ & $\mathrm{~N}$ & $\%$ & $\mathrm{~N}$ & $\%$ & $\mathrm{n}$ & $\%$ & $\mathrm{~N}$ & $\%$ & $\mathrm{n}$ & $\%$ \\
\hline Clerical Ability & 0 & 0 & 45 & 36.89 & 55 & 45.08 & 20 & 16.39 & 2 & 1.64 & 122 & 100 \\
\hline $\begin{array}{l}\text { Non-verbal } \\
\text { Ability }\end{array}$ & 0 & 0 & 56 & 45.90 & 44 & 36.06 & 19 & 15.57 & 3 & 2.46 & 122 & 100 \\
\hline $\begin{array}{l}\text { Visual } \\
\text { Manipulative } \\
\text { Ability }\end{array}$ & 8 & 6.56 & 36 & 29.51 & 40 & 32.79 & 36 & 29.51 & 2 & 1.64 & 122 & 100 \\
\hline
\end{tabular}

The study's findings supported that of Tan \& Balasico (2018), who reported the students' poor technical-vocational skills. The result can be explained in the type of curriculum and type of learning experiences the students are exposed to. It calls for teachers to strengthen the Technical-Vocational related subjects and adapt learning strategies that can enhance students' job-ready skills.

The last domain and another career track/strand are the Academic Track. It is composed of Humanities and Social Sciences (HUMSS), Science, Technology, Engineering and Mathematics (STEM), and Accountancy Business and Management (ABM) components. Table 4 portrays the frequency distribution of Grade 10 students' Aptitude Level on Academic Track subtests. Results show that most of the students in the HUMSS subtest fall into average to the high category, with $81.9 \%(\mathrm{n}=100)$. They are mostly clustered in the above-average aptitude. On STEM, 77\% of the students $(\mathrm{n}=94)$ belong to average to high aptitude, with notably 41 students with high aptitude. On the ABM strand, $60.6 \%$ of the students $(n=74)$ performed average to high aptitude, with 48 students who got a belowaverage aptitude. The data suggest that a greater number of students performed well in the HUMSS and STEM subtests.

Table 4

Frequency distribution of grade 10 students' aptitude level on academic track subtests

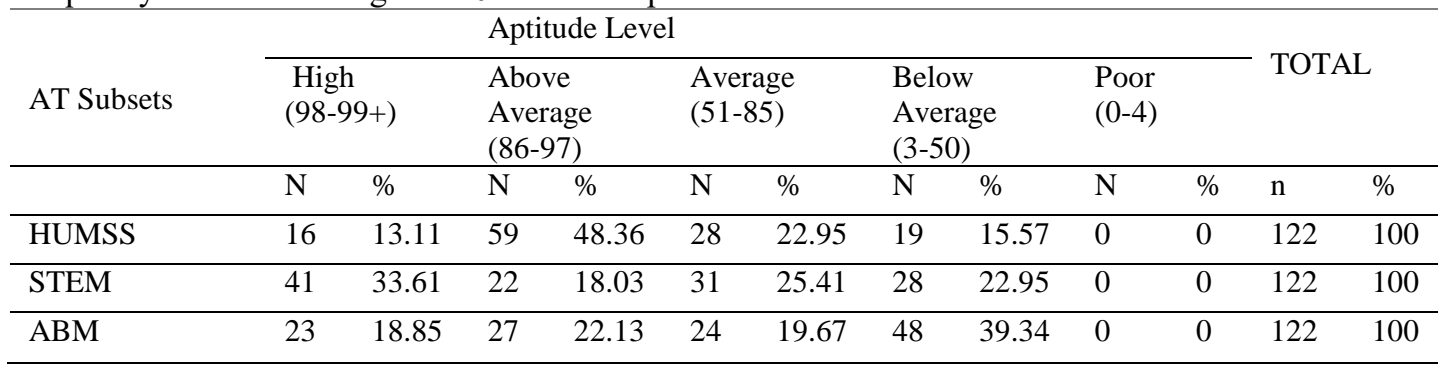

The results above agree with the Department of Education (2011) that the primary aim of NCAE is to assess students' aptitudes and skills and estimate what field or discipline they can excel in. This may imply that students have inclinations in Mathematics, Sciences, and Humanities and Social Sciences subjects. The study's result contradicts Camacho (2012) report that the inclination of graduating high school students is geared towards entrepreneurship, one of the main components in the ABM track. The result of the study calls for strengthening the development of knowledge, competencies, skills, and attitudes to enable the students to cultivate an entrepreneurial mindset and appreciate the role of enterprise in wealth, value, and employment creation from as early as pre-school to higher education 
levels (Camacho, 2012). Moreover, proper career assessment should be conducted to guide students in choosing the academic tracks where they have excelled or performed better (Ferrer \& Dela Cruz, 2017).

Table 5 presents the career/occupational interests of the students. Three (3) fields with the highest percentage scores were accounted for from each student. It shows that most of the students preferred the field of Natural Science ( $\mathrm{n}=51$; MPS=83.17). Natural Science has the highest mean percentage score and is high in terms of preference level. It was then followed by Spiritual Vocation $(n=42$; MPS=77) and Science $(n=42$; MPS=68.02), categorized as high preference. The field of Arts $(n=28$; MPS=79.24) was next in rank, followed by Military Services \& Excitement and Computers ( $\mathrm{n}=27$; MPS=82.41) and Technology and Community Services $(n=20$, MPS=80.19). Agriculture got the lowest mean percentage score $(n=12$, MPS=62.31). These suggest that students like Sciences subjects or STEM-related courses. Surprisingly, Spiritual Vocation is also one of the top picks indicating that students are willing to voucher in a religious life if given a chance. Surprisingly, agriculture is the last despite being an agricultural school. It may signify that students or teachers have not given the utmost importance to the field.

Table 5

Career/occupational interests of VSUIHS students

\begin{tabular}{llll}
\hline Career/Occupation & $\mathrm{N}$ & Mean Percentage Score (MPS) & Level of Preference \\
\hline A. Science & 42 & 68.02 & MP \\
\hline $\begin{array}{l}\text { B. Natural Science } \\
\text { C. }\end{array}$ & 51 & 83.17 & HP \\
\hline D. Agriculture & 12 & 62.31 & MP \\
\hline E. Engineering & 18 & 71.63 & MP \\
\hline $\begin{array}{l}\text { F. Business \& } \\
\quad \text { Finance/Commerce }\end{array}$ & 16 & 71.63 & MP \\
\hline G. Professional Services & 14 & 69.64 & MP \\
\hline H. Personal Services & 8 & 72.77 & MP \\
\hline İ. Computers \& Technology & 27 & 82.41 & HP \\
\hline J. Media \& Communication & 15 & 65.95 & MP \\
\hline K. Community Services & 20 & 80.19 & HP \\
\hline $\begin{array}{l}\text { L. Architecture and } \\
\quad \text { Construction }\end{array}$ & 18 & 72.60 & MP \\
\hline M. The Arts & 39 & 76.67 & HP \\
\hline N. Fashion & 15 & 69.67 & MP \\
\hline O. Military \& Excitement & 28 & 79.24 & HP \\
\hline P. Spiritual Vocation & 43 & 77.00 &
\end{tabular}

Several factors like the social environment influence the students' career preference, mainly the parents as an immediate family who plays an active role in choosing the right education for their children (Pafili \& Mylonakis, 2011, in Aguado, Laguador \& Deligero, 2015). It also includes gender, academic-related, socio-economic factors, and personal qualities of the student (Aguado et al., 2015). The integration of career plans in the curriculum can help students make decisions in career selection (Pascual, 2014). Helping the students select the right track will help them ready for their future. It can also enhance their capabilities and skills in the track they want to pursue (Moneva \& Malbas, 2019). Interventions that will enhance human resource development planning, career guidance, and counseling, and school-industry partnership must be strengthened and be put in place (Camacho, 2012). Moreover, Mamolo and Sugano (2020) found that factors such as negative perception and lack of students' self-confidence, not conducive learning environment, ineffective and efficient teaching, 
and students' reasons are identified as the primary reason behind student's performance towards a subject matter.

Table 6 portrays the independent samples T-test on the students' standard scores on the TechnicalVocational Aptitude (TVA) and Academic Track (AT). Results show that there is a significant difference between the two $(t=-2.598, p=0.010)$ domains. Moreover, students tend to have higher AT domains $(M=607.16, S . D .=109.85)$ than in the TVA test $(M=572.31, S D=99.50)$. Results signify that the Grade 10 students performed better in the Academic Track. Thus, its strength is in Math and Sciences subjects than TVA related subjects.

Table 6

Independent samples t-test on standard scores of technical-vocational aptitudes (TVA) and academic track (AT)

\begin{tabular}{llllll}
\hline Track & & N & Mean & Std. Deviation & Significance \\
\hline \multirow{2}{*}{ Scores } & TVA & 122 & 572.31 & 99.50 & $0.010^{*}$ \\
& AT & 122 & 607.16 & 109.85 & \\
\hline
\end{tabular}

Mamolo (2019) presented that the academic track is significantly different from the TVL track because the former's inclination is into the academe, while the latter is more into skills and knowledge development for vocational jobs. He also cited that academic track students' competency score was significantly higher than the mean competency score of the matched group of non-academic track students.

The significant relationships between students' academic performance in Science, Mathematics, and English and their NCAE Scores in the three GSA subtests were also analyzed. Table 7 shows the Pearson r Correlation of Scientific Ability to the Performance in Science of the students. The grades in science was correlated with their scores in the Scientific Ability subtest. It was revealed that there was no significant relationship between the two variables $(p=0.276, r=0.099)$. Hence, the students' aptitude in Scientific Ability, as reflected in NCAE results, has no significant association with their class performance in science. It means that if the students obtained a high grade in Science, there is no guarantee that they would likely get a high score in the Scientific Ability test or the other way around.

Table 7

Pearson $\mathrm{r}$ correlation of scientific ability to the academic performance in science

\begin{tabular}{cllll}
\hline Variables & Mean & SD & Correlation & Significance \\
\cline { 1 - 3 } Scientific Ability & 591.53 & 125.51 & \multirow{2}{*}{0.099} & 0.276
\end{tabular}

Table 8 shows the Pearson $r$ Correlation of Mathematical Ability to the students' Academic Performance in Mathematics. Results show that there is a significant relationship between the two variables $(p=0.041, r=0.185)$. Moreover, results indicate a weak positive correlation between the M.A. score and the students' mathematics grades. It means that students who performed well in Math class would likely perform well and get a high score in the NCAE MA test. Also, students who have low Mathematics grades would likely achieve low aptitude levels in the NCAE Mathematics Ability subtest. 
Table 8

Pearson $r$ correlation of mathematical ability to the academic performance in mathematics

\begin{tabular}{|c|c|c|c|c|}
\hline Variables & Mean & SD & Correlation & Significance \\
\hline Mathematical Ability & 581.01 & 119.26 & 0.185 & $0.041^{*}$ \\
\hline Academic Performance in Mathematics & 83.78 & 4.23 & & \\
\hline
\end{tabular}

The findings support the study of Ferrer and Dela Cruz (2017) and Mirabueno and Boyon (2020) that a positive correlation was observed between mathematical ability and students' academic performance. Stepwise linear regression analysis also indicated that mathematical ability is a predictor of academic performance (Tan \& Balasico, 2018).

Lastly, the students' English academic performance's association to their aptitude in Reading Comprehension and Verbal Ability was performed. Table 9 presents the Pearson $r$ Correlation of Reading Comprehension and Verbal Ability to the Academic Performance in English. Results show that there is no significant association between English grade and R.C. and V.A. scores $(p=0.328, r=$ 0.089).

Table 9

Pearson $r$ correlation of reading comprehension and verbal ability to the academic performance in English

\begin{tabular}{lllll}
\hline Variables & Mean & SD & Correlation & Significance \\
\cline { 1 - 2 } Reading Comprehension and Verbal Ability & 601.59 & 94.02 & 0.089 & 0.328 \\
\cline { 1 - 2 } Academic Performance in English & 87.32 & 6.27 & & \\
\hline
\end{tabular}

It denotes that if the students performed well in the English class, it does not necessarily mean that they also excel in NCAE Reading Comprehension and Verbal Ability subtests. Moreover, this also indicates that if students have low English grades, they must also have a low aptitude level on R.C. and V.A.

\section{CONCLUSION}

This study aimed to describe and correlate the student aptitude and academic performance of Grade 10 students. The overall NCAE performance in the three domains, GSA, TVA, and AT was accounted for based on the aptitude level. Majority of the students performed on the average to high aptitude level. Moreover, results show that Reading Comprehension, Clerical and Non-verbal Ability, and STEM track were performed better in the GSA, TVA, and AT domains. It was also found that Natural Science, Spiritual Vocation, and Science were the students' top career/occupational interests. The Grade 10 students performed well in the Academic Track than in the Technical-Vocational Aptitude Test and were found to be a career strength for Senior High School. There is a weak positive relationship between Math Grade and Mathematical Ability Score. However, no significant association was observed in the correlation analysis of Science and English academic performance to the GSA Scientific Ability, Reading Comprehension, and Verbal Ability performance. The results show that students preferred the STEM track than others because VSUIHS offers additional subjects in Mathematics and Sciences compared to the other high schools in the region with different curricula. Furthermore, students have been screened from the entrance exam in their Grade 7 up to their grade 10. 


\section{RECOMMENDATIONS AND IMPLICATIONS}

Based on the study's findings, it is recommended that teachers and the school provide an evaluation and monitoring program with provisions to motivate students to perform better in the NCAE or other national standardized exams. Guidance Counsellors should also make a scheme that will record, assess, and follow-up students' performance in every NCAE exam. The school should create or develop a career guidance program intended for the utilization and discussion of NCAE results to every student and parents to make the students' wiser career choices. Also, analysis in the students' whole grades (GPA) would be useful in the students' assessment in determining the strength in other fields of specialization like arts, sports, and social sciences.

Results show that the students' top career/occupation preference was on Natural Science, Spiritual Vocation, Science, Arts, Computers, and Technology. Natural Science, including Allied Medical Science and Computers \& Technology, were one of the specialized fields in the Academic Track for Senior High School. As revealed in the results above, it shows that the Grade 10 students' career strength is on Academic Track. They obtained high scores and did perform well on the three components, especially on Humanities and Social Sciences (HUMSS) and Science, Technology, Engineering, and Mathematics (STEM). It can then be implied that with the two career tracks being tested, the Academic Track is the more suitable career track/strand for Senior High School of this set of students, especially on STEM. Hence, the students' career interest and career strength should be of primary considerations in proposing a certain program. Thus, the result of this study may provide insights to curriculum planners and school administrators on the skills, knowledge, and career track to be taught and offered as to the demand of the senior high school program.

On the other hand, results may imply that most students do not choose to proceed to agriculture courses despite being an agricultural school. This may indicate that the training/curriculum that the learners were trained with does not necessarily mean that learners opt to follow the track. Hence, training institutions must still develop a curriculum where all learners of different intelligences, as highlighted by Howard Gardner, will be catered. However, if the curriculum intends to develop skills in certain fields, additional laboratory set-up, job training, practicums, and many others may be integrated into the curriculum. By these means, the agricultural school may be able to produce students who prefer agriculture-related courses.

This paper was presented in the $4^{\text {th }}$ International Conference of Science Educators and Teachers (ISET), Khon Kaen, Thailand: Science Education Association (Thailand) (SEAT).

Acknowledgments:

The corresponding author is very grateful to the following individuals for sharing their expertise and refining this study; Dr. Manuel B. Barquilla and Dr. Myrna T. Lahoylahoy.

\section{REFERENCES}

Alonzo, R.I. (2015). Understanding the K to 12 Educational reforms. Philippine Social Sciences Review, 67, pp. 1-15.

Aguado, C.L., Laguador, J.M. \& Deligero, J.C.L. (2015). Factors affecting the choice of school and students' level of interest towards the maritime program. Asian Social Science, 11(21).

Bhardwaj, A. (2016). Importance of Education in Human Life: A Holistic Approach. International Journal of Science and Consciousness, 2(2), pp. 23 - 28.

Benita, N.V. (2015). National conference on the administration of the NCAE, PEPT and TEPT-PST. 
Camacho, J.V. (2012). Philippine basic education system towards the cultivation of culture of entrepreneurship and innovation. Osaka University Knowledge Archive, 17(1), 57-68.

Department of Education (2011). K to 12 basic education program primer deped updates. Retrieved from http://www.deped.gov.ph/

Department of Education. (2011). New Guidelines and Date for National Career Assessment Examination (NCAE). Retrieved from http://www.gov.ph/2011/08/26/new-guidelines-and-date-fornational-career-assessment-examination-ncae/

Department of Education (2013). Implementing rules and regulations of the ENHANCED basic education act of 2013. Retrieved from https://www.officialgazette.gov.ph/2013/09/04/irr-republic-actno-10533/

Ferrrer, F.P. \& Dela Cruz, R.J. (2017). Correlation of stem students' performance in the national career assessment examination and academic subjects. PEOPLE: International Journal of Social Sciences, 3(1), $532-541$.

Mamolo, L. (2019). Analysis of senior high school students' competency in general Mathematics. Universal Journal of Educational Research, 7(9), 1938 - 1944. Doi:10.13189/ujer.2019.070913

Mamolo, L. \& Sugano, S.G. (2020). Self-perceived and actual competencies of senior high school students in general mathematics. Cogent Education, 7(1). (On press)

Mirabueno, J.A.S. \& Boyon, M.C.L. (2020). Senior high school academic progression in mathematics. PEOPLE: International Journal of Social Sciences, 5(3), 840-849.

Masuhay, E.P. \& Herrera, F.T. (2019). Globalization has changed the system of education, shaping the education doesn't make any changes. Global Scientific Journals, 7(1), pp. 163 - 178.

Moneva, J.C. \& Malbas, M.H. (2019). Preferences in senior high school tracks of the grade 10 students. IRA International Journal of Education and Multidisciplinary Studies, 15(5), 167-174. doi: http://dx.doi.org/10.21013/jems.v15.n5.p2

Olaniiran, S.O. (2016) Revisiting UNESCO Four Pillars of Education and its Implications for the 21st Century Teaching and Learning. 1st Teaching and Learning Conference.

Oliveros, A. (2013). Analysis of the National Career Assessment Examination (NCAE). Retrieved from https://prezi.com/exydfaksbvqw/analysis-of-the-national-career-assessment-examination-ncae/

Pascual, N.T. (2014). Factors Affecting High School Students' Career Preference: A Basis for Career Planning Program. International Journal of Sciences: Basic and Applied Research (IJSBAR), 16(1), 114.

Rao, P.S. (2018). Evaluation and assessment in ELT: A global perspective. Research Journal of English Language and Literature, 6(2).

Tan, D. A. \& Balasico, C. L. (2018). Students' academic performance, aptitude, and occupational interest in the national career assessment examination. PUPIL: International Journal of Teaching, Education and Learning, 2(3), 01-21.

The Correlation of NCAE Examination and the academic performance of the students. Retrieved from http://www.studymode.com/essays/The-Correlation-Of-Ncae-Examinations-And-532596.html\#loaded

Thompson, D. (2009). Why standardized testing is important? Retrieved from https://www.triangleeducationassessments.com/content/pdfs/standardizedtesting.pdf 
UNESCO. (2010). Principles and general objectives of education. Retrieved from http://www.ibe.unesco.org/fileadmin/user_upload/Publications/WDE/2010/pdfversions/Philippines.pdf

Wagner, A.T. (2016). A global perspective: Bringing the world into classrooms. Retrieved from https://www.edweek.org/tm/articles/2016/08/03/a-global-perspective-bringing-the-world-into.html 